\title{
СВЯЗЬ ГЕРИАТРИЧЕСКИХ СИНДРОМОВ И ГЛИКИРОВАННОГО ГЕМОГЛОБИНА У ДОЛГОЖИТЕЛЕЙ
}

Браилова Н.В., Дудинская Е.Н., Ерусланова К.А., Шарашкина Н.В, Мачехина Л.В, Ткачева О.Н.

ФГАОУ ВО «Российский национальный исследовательский медицинский университет им. Н.И. Пирогова» Минздрава России, Российский геронтологический научно-клинический центр, Москва

ЦЕЛЬ: определить взаимосвязь гликированного гемоглобина с гериатрическими синдромами у долгожителей

МАТЕРИАЛЫ И МЕТОДЫ: в продольное исследование включено 82 пациента, проживающих в Москве

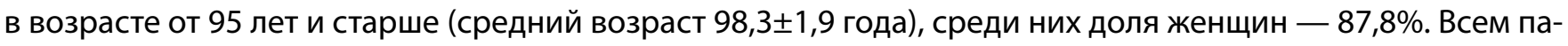
циентам выполнена комплексная гериатрическая оценка (КГО) с использованием шкал: Возраст не помеха, Бартел, IADL-C, MNA, GDS-15, MMSE, определение уровня гликированного гемоглобина (НbА $)$ и липидного спектра (общий холестерин, триглицериды, липопротеины высокой и низкой плотности), оценка качества жизни с помощью анкеты QoL. Через год осуществлялся телефонный контакт с родственниками пациентов для оценки их состояния. Статистический анализ был выполнен с использованием пакета IBM SPSS Statistics версии 26. Статистически значимыми были различия с $p<0,05$.

РЕзУЛЬТАТЫ: в изучаемой группе долгожителей 34,4\% пациента имели старческую астению, 56,2\% преастению по данным опросника «Возраст не помеха». По результатам опроса 84,4\% пациента имели сенсорные дефициты, 95,3\% - ограничение мобильности, 70,3\% - когнитивные нарушения, у 17,2\% выявлено снижение массы тела. По результатам КГО у значительного числа пациентов выявлено снижение базовой повседневной и инструментальной активности (53 (82,8\%) и 62 (96,9\%) соответственно), эмоционального фона (55 (86,9\%)). Когнитивные нарушения разной степени выраженности были у 55,6\% пациентов. Медиана $\mathrm{HbA}_{1 c}$ составила 5,8\% [5,6; 6,1], показателей липидного профиля: общий холестерин 4,8 [4,2; 5,8], триглицериды - 0,97 [0,8; 1,2], лПВП - 1,3 [4,2; 5,8), лПНП - 3,1 [2,6; 3,7].

Уровень $\mathrm{HbA}_{1 c}<6 \%$ был у 59\% пациентов; от 6\% до 6,4\% - у 33\% пациентов и >6,5\% - у $8 \%$ пациентов. У 2 пациентов (3,2\%) сахарный диабет (СД) 2 типа был более 5 лет, у 3 пациентов - СД 2 типа менее 3 месяцев, без сахароснижающей терапии. Окружность талии составила 92 см [80; 100], индекс массы тела 24 кг/м² [21;28]. Не было выявлено корреляции между НbА и ировнем липидов. Не обнаружена взаимосвязь $\mathrm{HbA}_{1 с}$ с показателями КГО, в т.ч. когнитивными нарушениями, и качеством жизни, за исключением прямой взаимосвязи в однофакторном анализе со статусом питания по шкале $M N A(t=2,454 ; p=0,022)$. Однако установлено, что количество гериатрических синдромов по данным опросника «Возраст не по-

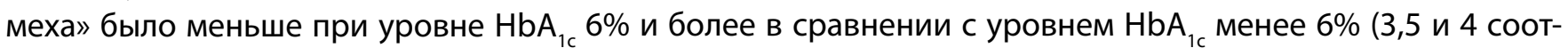
ветственно, p<0,05, тест Mann-Whitney). При сравнении групп выживших и не выживших не обнаружено значимых различий в уровне $\mathrm{HbA}_{1 c}(p>0,05)$.

Выводы: у долгожителей гликированный гемоглобин не влияет на выживаемость, качество жизни и когнитивные нарушения, но влияет на функциональное состояние. Необходимы дальнейшие исследования углеводного обмена у пожилых людей для создания персонализированного подхода к таким пациентам, своевременного выявления и уменьшения выраженности проявлений гериатрических синдромов, что может предотвратить снижение функционального и когнитивного статуса и продлить активное долголетие.

КЛЮЧЕВЫЕ СЛОВА: долгожители; гериатрические синдромы; гликированный гемоглобин; когнитивные нарушения. 